\title{
Analysis of solar energy technology in leading countries
}

\author{
Kannan Kaliappan ${ }^{1}$, M Sankar ${ }^{2}$, B Karthikeyan ${ }^{3}$, Budamkayala Vineeth $^{4}$, V.Chetan Raju ${ }^{5}$ \\ 1,4,5 Departement of Electrical and Electronics Engineering, SNIST ,Hyderabad, India. \\ ${ }^{2}$ Ashok Rao mane group of Institutions, Maharashtra, India. \\ ${ }^{3}$ Sethu Institute of Technology, Viruhunagar, Tamilnadu, India.
}

\begin{tabular}{|c|c|}
\hline Article Info & ABSTRACT \\
\hline $\begin{array}{l}\text { Keywords: } \\
\text { Renewable Energy } \\
\text { Solar Energy } \\
\text { Photovoltaic Systems } \\
\text { Clean Energy }\end{array}$ & $\begin{array}{l}\text { In the present generation energy plays a vital role in our world and for human } \\
\text { life it's very important factor. There is a methodical meeting taking place } \\
\text { regarding the conservation of energy and every time there is a review in the } \\
\text { agenda. Energy demand and supply were endeavored by these countries. To } \\
\text { rectify these problems, there should be more research in the generation of } \\
\text { energy with the greater efficiency and try to use energy in more efficient } \\
\text { manner. Solar energy remains as the most prominent source of energy as it is } \\
\text { cost effective and environmentally friendly. Reviews convey that solar } \\
\text { energy systems will play a major role in the power generations. As per } \\
\text { present scenario there is a great importance to the solar energy using } \\
\text { photovoltaic systems. Photovoltaic systems exhibit an important role for } \\
\text { solar energy production. } \\
\text { Copyright } @ 2019 \text { Institute of Advanced Engineering and Science. } \\
\text { All rights reserved. }\end{array}$ \\
\hline \multicolumn{2}{|l|}{ Corresponding Author: } \\
\hline \multicolumn{2}{|c|}{$\begin{array}{l}\text { Kannan Kaliappan, } \\
\text { Departement of Electrical and Electronics Engineering, } \\
\text { Sreenidhi Institute of Science and Technology, } \\
\text { Yamnampet, Ghatkesar, Hyderabad, India. } \\
\text { Email: kannankmeped@gmail.com }\end{array}$} \\
\hline
\end{tabular}

\section{INTRODUCTION}

In the previous years, due to increase in people and global economic which requires additional energy is vital not only for the growth of socio-economic but also for the developed countries [1]. The energy plays a vital role in all sectors. For the existence universal agreement, there should be an effective energy policy which should consist of regulatory instruments, economic incentives, information provision and with the individual country respective measures [2]. Renewable energy is a sustainable and fresh source of energy which is derived from the nature. Renewable energy will be the solution in the future, which transforms natural phenomena into useful energy. There is a concern regarding the development of applications and the lectures of renewable energies which has got its pace in past years. There are some research centers which have been completely developed for the renewable energies.

It shows that the prices fossil fuel and the electricity prices have risen continuously, since last few years. Through the utilization of the renewable power generation systems large amount of the energy will be saved and a great contribution will be made to environment through an increase in users of it, also there will be protection of the environment as there is a reduction in the carbon dioxide emission and its effects. Throughout the world there is an issue on the global warming which is due to the emissions of the carbon dioxide. In most of the countries, the huge amount of the $\mathrm{CO} 2$ is emitted through the electric power generation. This global warming has a significant impact on the climate change which is a major issue, which is widely discussed and debated throughout the globe. Due to the regular human activities there is a major cause in a climate which is due to the excessive emission of greenhouse gases like carbon dioxide, methane and so on. In the recent years, environmental issues have intentioned to every individual in the world and solar power generation is a method of solving the energy related issues which is gaining unprecedented attention. Compared with any other energy source, the photo voltaic energy is non-polluted and has many 
benefits. As per the availability of global solar radiation, the proper design of solar energy conversion system with exact knowledge is required. Sunshine hours at many locations are measured around the world but the global radiation is measured at selected locations only. To utilize this energy at night hours a proper energy storage system is required which must be capable of accumulating the energy efficiently. Among other energy methods of sustainable energy sources, the photovoltaic energy method is quite attractive for electricity as it is noiseless, no $\mathrm{CO} 2$ emissions during the operation, scale flexibility and less maintenance. To solve the environmental problems throughout the world, the clean energy source photovoltaic (PV) has received a considerable attention. Beside PV having the environmental benefits, it avoids the risk of fossil fuel disruption and associated price instability. Therefore, a significant contribution of the renewable energies is the supply security. The photovoltaic energy can be used in wide range applications like power supply for small consumer products to large power stations feeding electricity into the grid. Over the past five years, in the photoelectric industry has an average growth rate of $49.5 \%$ around the world.

The above Figure 1 shows that in 2007 the world solar PV market installations reached a record high of $5.95 \mathrm{GW}$, in the previous year they have a growth of $110 \%$ and now in China, it will again take the leading share by 2017 in the total annual PV demand. China pertains to $48 \%$ of the entire Global demand. Whereas India and USA contribute almost equal in the Global Demand. Solar energy as well as the solar PVs has a vast sustainable energy potential compared with global energy demand. The International Energy Agency (IEA) envisaged solar power accounting for $11 \%$ of the global electricity production by 2050 and solar electricity contribution around $20 \%$ of the world energy supply offer 2050 and $60 \%$ by 2100 .

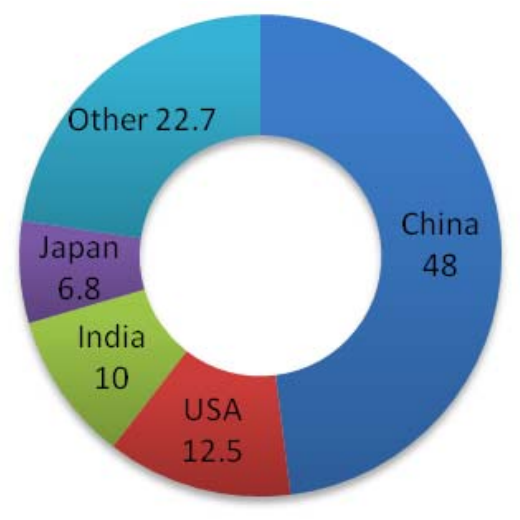

Figure 1. Distribution of Global Annual PV Demand

It's clear that the major role in future of the electric power generation will be with PV cells. The development of PV systems will increase and focus more on the PV industry that is poised for exponentially reduction of their cost. In few years there will be major development. In next 5-10 years, it is conditional in many countries that alternative energy should be provided with many incentive methods to bring down the cost of investments. There may be a roughly equal share divided among the photovoltaic and concentrating solar energy [3].

Around 50 years ago, at the early days of photo voltaic, the required to produce a PV panel was more than the energy that is produced by the panel during its lifetime. In the last decade, due to the improvements in the efficiency of panels and manufacturing methods, the payback time was reduced to 3-5 years, and based on the obtained sunshine at the installation site. These days the cost of the photovoltaic is around \$2.5 US per watt peak and the target is to reduce to \$1 US/W peak by the 2020[4]. The major production of the photovoltaic was around 1990 to 2006, but the major market was in 2006 as it rose more than $40 \%$. The reduction of cost is achieved through following measures:

(i) Higher conversion efficiency,

(ii) Less material consumption,

(iii) Application of cheaper materials,

(iv) Innovation in manufacture,

(v) Mass production and

(vi) Optimized system technology

Int J Pow Elec \& Dri Syst Vol. 10, No. 4, Dec 2019 : 1995 - 2004 


\section{CHINA}

Energy is significant in the core sector. The second largest electricity supply system in the world is PRC. The global warming is due to the coal where around $65 \%$ of primary energy is produced from it. In 2005 , the China's total primary energy consumption is due to coal which is of $68.7 \%$, in the same year the OECD countries was about $21 \%$. The highest carbon intensity among fossil fuels is due to the coal, the coalfired plants have the highest output rate of $\mathrm{CO} 2$ per $\mathrm{KWh}$. This situation creates a serious threat to global warming. The basic needs throughout the world are the energy, such as the food and the shelter. Particularly in China, which is a developing country with a population of 1.25 billion, energy is hugely required for its fast growth in economic. Over the last two decades, the economic growth is nearly $10 \%$ per year, China's energy consumption has been rapidly increasing. Considering the requirements of energy and it's features, energy technology development is significant for the China's sustainable development. However, China has extremely rich solar energy resources, but the new electricity generation capacity is most from the fossil fuels. As the renewable electricity capacity and generation has a share of the total capacity by which there will be decrease in generation rather than increment. With this in view, there is a reason for not being optimistic about future China's carbon emissions. For action on the renewable energy development, China is at critical crossroads. In the recent years, the government of China has implemented State Technical problem tracking Plan, high technology research plan, industrialized development special item and key special item, etc. Through these, there is a support from the government on the utilization of solar energy, photovoltaic power generation and in terms of photovoltaic power generation products. Regarding the China's solar energy economy and its important situation among all of the countries, there are many case studies. The PV industry of China is growing much faster than any other country in the world. From year-on-year, the popularity of solar power is growing and also the installation capacity. In the year 2016 solar PV is the second-most positioned renewable technology and accounted for $43.3 \%$ of the newly installed renewable power capacity, followed by wind and hydropower at $32.7 \%$ and $17.7 \%$ respectively. The Figure 2 shows the annual solar PV capacity installations in the China from 2007-2017.

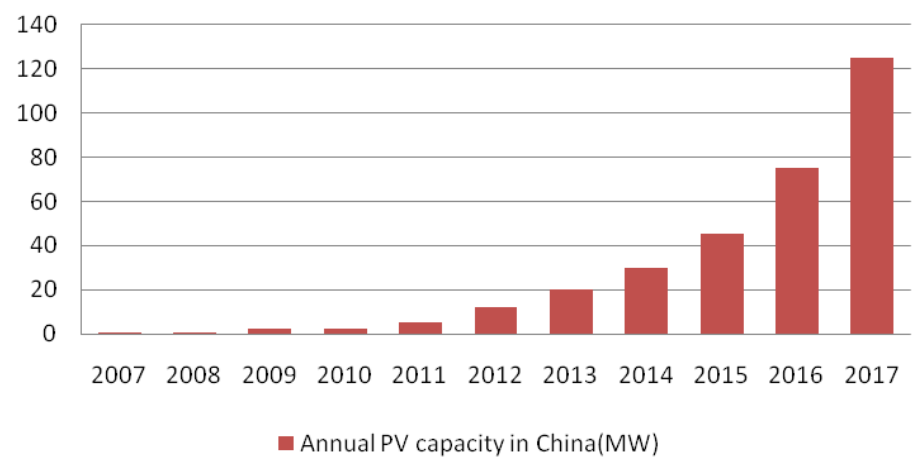

Figure 2. Annual PV installed Capacity in China

In 2016 the Asia-Pacific (APAC) has the total capacity of 52.38MW and also surpassed the annual PV installations in Europe. Annual PV capacity in China is intensified every year and sets as a trademark for every developed nation. In the years 2016 and 2017 the capacity was almost doubled and showcasing the importance of Renewable Energy Sources. Some other world's bigger solar PV component manufacturers in the APAC countries are Japan, China and Taiwan. By supporting long-term policies and providing financial incentives and subsidies by the APAC governments for the solar module manufacturing, this helps in the further market drive. In 2016, within the APAC region, China was the biggest PV market with cumulative installed capacity of $77.5 \mathrm{GW}$ [5-7]. With the addition more than $223 \mathrm{GW}$, the country is expecting to continue the dominate the market in the forecast period. The Chinese government planned to support and to increase the non-fossil fuel power generation to $20 \%$ by 2030 [8]. The government aimed to invest CNY2.5 trillion (\$364bn) in the renewable power generation sector by 2020 .

\section{UNITED STATES OF AMERICA}

The 624MW power generation in US which is third largest PV market of the PV installation in 2006 and a cumulative PV installed overall capacity can be around $1.45 \mathrm{GW}$. There was a drastic growth in PV 
installation during 2000 to 2008 where it grew from 4MW to $290 \mathrm{MW}$; the average rate is increased by $71 \%$ per annum. Through this rapid growth made the US as third largest global demand center behind the Germany and Spain. Only the US has the potential to engender sustainability and long-term market. With ample availability of land for PV development, with high insulation and the greatest demand of electricity in the world, US presents an attractive opportunity for the long-term growth for developers, installers, financiers and other PV service providers. Most global industries recognized this potential and are seeking to develop and refine the market strategy of US.

In the next 4 years, the US will experience most rapid demand of any major PV market. By 2012 the base case of US PV demand may grow to the $1515 \mathrm{MW}$, the average annual growth was $48 \%$ from 2008 to 2012. The scenario sees demanding may reach up to 2022MW in 2012. In this period, the US surpasses Spain to become the second leading PV market in the world behind Germany. The Figure 3 shows the annual solar PV capacity installations in the US from 2005-2017.

The Annual PV capacity in US was increasing every year from 2005-2016. It has decreased a little in 2017. US trying to maximize its reach ability in renewable sources. The goal of the industry is to meet $10 \%$ of US peak electricity generation capacity by the $2030[8,9]$. The PV industry expects to employ more than 150000 people in US and grows up to $\$ 15$ billion industry by the next 25 years [10]. To reach the required goals, the following scenario has been developed. The production target of the US PV-industry reveals that $70 \%$ of the production capacities are aimed for the export. The Japan which is having a strong market, where its accelerating the expansion of production capacities is lagging in the US. This may be the reason for which the US lost its market leader position held for many.

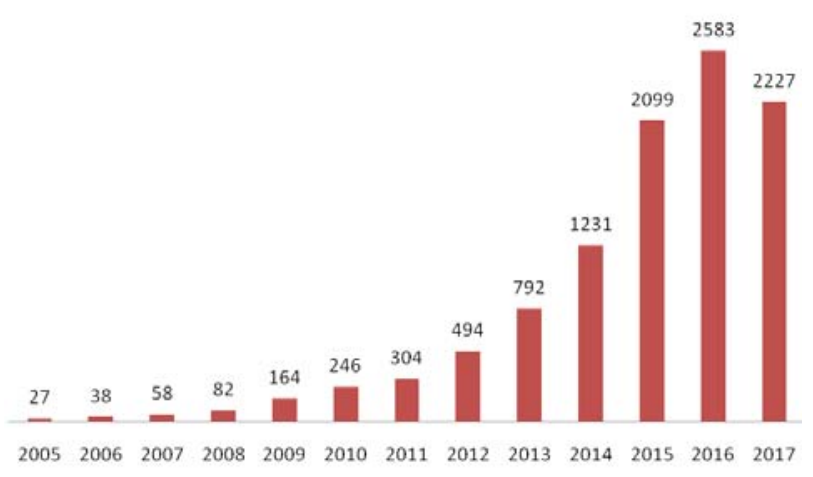

Figure 3. Annual Solar PV capacity Installations in United States

\section{SOUTH KOREA}

Last year South Korea reached to its maximum renewable capacity by installing $13 \mathrm{GW}$. As stated by the Ministry of Trade, Industry and Energy (MOTIE), their target is to reach $20 \%$ renewable share which is not high of global standards, for this the country have to increase by $57 \mathrm{GW}$ in the next 13 years. They were lacking the land for installing solar and wind plants, and there is a key obstacle to develop renewable that is local opposition, and decided to improve regulations; overcoming hostility by getting members of the public involved projects; getting public corporation and involvement of local authorities; creating jobs and developing industries. The main issue is lack of space. Much of the South Korean terrain contain wooded mountains which are considered to be unsuitable for installing solar or wind farms, whereas farmland considered for a good part of remainder. Tesla founder and renewable energy pioneer Elon Musk recently said that all of the united states' demand electricity can be met by just one giant solar farm covering a 100 square miles long, but South Korea doesn't have large expenses of scrubland or desert available for a similar megaproject. Through utilization of space in novel way, solar plants are appearing in some places. Korean Rural Community (KRC) which is planning to build 3 new floating solar farms, in which 2 farms capacity is $100 \mathrm{MW}$ and other one with $80 \mathrm{MW}$, on lakes - by comparing, the floating solar farm that went online in Huainan, China to much fanfare earlier this year which has a capacity of 40MW.South Korea being a top nation in the stream of electronics dilating its ability in the stream of renewable energies. The Figure 4 shows the South Korea annual production of renewable energy sources in 2017. The dependency on solar is reaching drastically when compared to other sources. In 2016, the photovoltaic capacity of country was

Int J Pow Elec \& Dri Syst Vol. 10, No. 4, Dec 2019 : 1995 - 2004 
increased by $25 \%$, from $3.5 \mathrm{GW}$ to $4.4 \mathrm{GW}$ - which is seventh biggest increase of any country worldwide. More than $0.5 \mathrm{GW}$ was installed in the first half of 2017 , and this year $1.2 \mathrm{GW}$ of new solar capacity given from July to December which is $20 \%$ greater than in January to June. Solar was leading ahead of the wind, but for the first time in South Korea installed a capacity of $1 \mathrm{GW}$ in the year 2016. In the same year, the country got its first offshore wind plants- generally offshore winds benefits for higher winds speeds and less opposition from local. The Figure 5 shows the south Korean renewable energy power generation versus total power generation in the year of 2005- 2016 and especially the commercial PV systems are usually installed and the total cumulative capacity of the commercial PV systems was $4450 \mathrm{MW}$ in 2016[11].
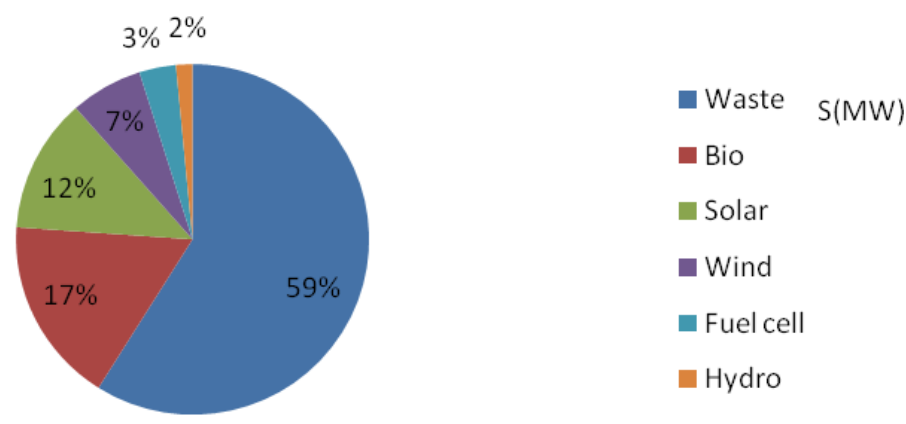

Figure 4. Production of energy in \% of renewable sources

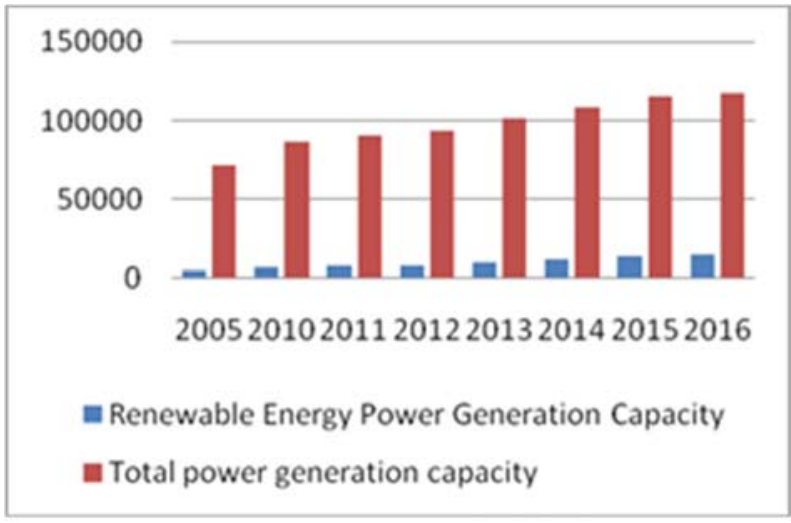

Figure 5. Renewable energy power generation capacity with total power generation capacity

South Korea is planning to increase its solar generation capacity to 5 times by 2030 and to enhance the use of renewable energy sources. The country is now trying to capture the fractions of their available renewable resources, as the South Korea is having low share of renewable. In May, when president Moon Jae came to power, he suggested to cut dependency on nuclear power, in favor of "environmental-friendly" energy resources in his government has cut up plans to build 6 more reactors. The world's 5th-biggest nuclear energy user is currently operating 24 nuclear reactors which generate a 3rd of its total electricity needs. "We will fundamentally change the way renewable energy is developed by creating an environment where the public can easily participate in the renewable energy business," said Paik Un-gyu, Minister of Trade, Industry and Energy. South Korea plans to provide a fifth of the country's total amount of electricity from renewable energy by 2030, up from 7 percent in 2016. To meet that goal, it plans to add $30.8 \mathrm{GW}$ of solar power generating capacity and $16.5 \mathrm{GW}$ of wind power capacity by 2030 [12].

The Figure 6 shows the annual solar PV capacity installations in the US from 2010-2020.As of 2017 , South Korea has $5.7 \mathrm{GW}$ of generating capacity from solar power and $1.2 \mathrm{GW}$ from wind power. The additional capacity will come from major projects, as well as by converting individual households, farms and small businesses to renewable energy, the ministry said. South Korea aims to have one out of 30 households equipped with solar power generation by 2022 , the ministry said, and to emphasize renewable energy projects with generating capacity of about 5GW between 2018 and 2022. 


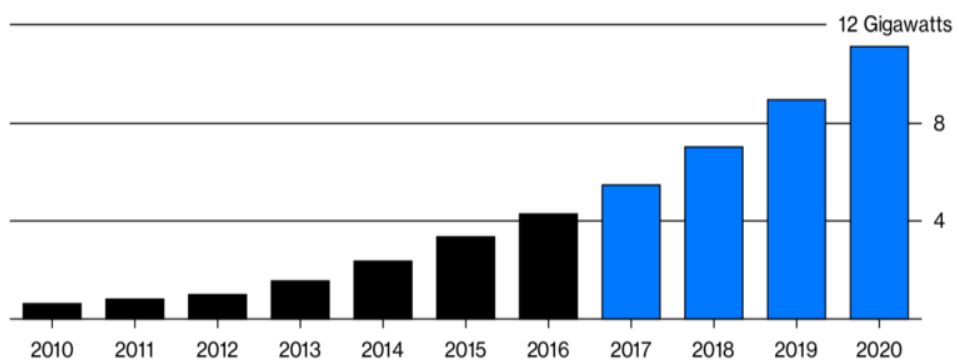

Figure 6. Annual Solar PV capacity Installations in South Korea

\section{INDIA}

There is a low-level growth in the world business, but Indian economy maintains its large development in renewable energy sources. There was a model shift in the Indian economy in the year 201617 which will function by focusing on laying infrastructure for widespread inclusion of all economic activity on digital platform. In the Indian economy the major role is played by the power sector and it is growing exponentially. Now the total installed capacity has increased to $310 \mathrm{GW}$ with the mix of different generations of Thermal (57.44\%), Renewable (19.43\%), Hydro (13.38\%), Gas (13.38\%), Nuclear (2.02\%) and Diesel $(0.25 \%)$. It shows that the renewable power has secured $2^{\text {nd }}$ position after Thermal and is spreading its wings rapidly in India like Wind (9.7\%), Solar (5.79\%), Bio-power $(2.5 \%)$ and small Hydro $(1.32 \%)$ in the below Figure 7

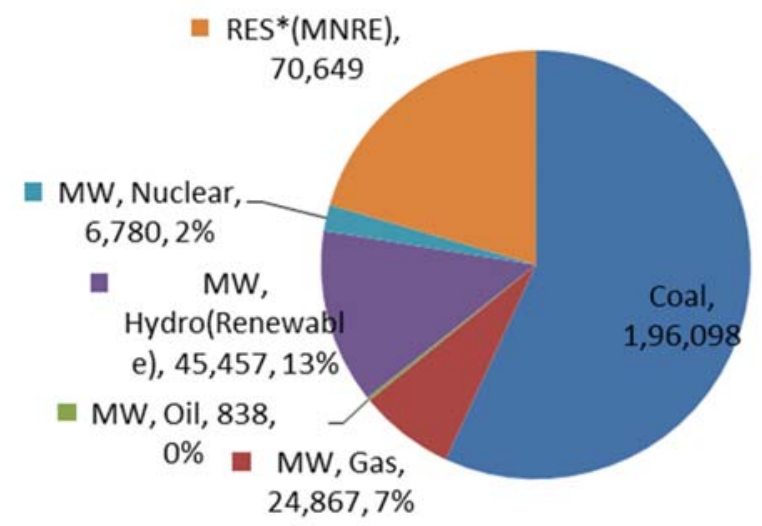

Figure 7. Source wise power installed capacity as on Dec -2017

By 2022 the government of India is to upscale its renewable power capacity to $175 \mathrm{GW}$ in which $100 \mathrm{GW}$ from Solar, $60 \mathrm{GW}$ from wind, $10 \mathrm{GW}$ from bio-power and $5 \mathrm{GW}$ from small hydro power. To achieve this target the ministry is implementing a wide range of schemes with financial support and conductive policies. In the term 2015-16, the largest ever addition of wind capacity with 3423MW with extending aim by $43 \%$ and the capacity of solar power extending by $3019 \mathrm{MW}$ and more extending target of $116 \%$. In 2015-16 the installation was higher than the past 24 years where the largest ever solar power projects capacity of 20904MW was tendered and 31472 solar pumps were installed [13,14]. The Ministry of New and Renewable Energy (MNRE) is the nodal Ministry at the federal level for all matters relating to new and renewable energy. The broad spectrum programs with harnessing renewable power have been implemented by the Ministry, in the rural areas the renewable energy is for lighting, cooking and motive power whereas in the urban areas it's utilized for industrial, commercial applications and development of non conventional energy.

Int J Pow Elec \& Dri Syst Vol. 10, No. 4, Dec 2019 : 1995 - 2004 
The Figure 8 acknowledges us about the various renewable resources installed capacity in MW, where the major contribution is by the wind energy resources which is $49 \%$ of overall installed capacity then it's continued by the solar energy which is of \% and still there is ongoing increase in proportion of the solar power and the next is continued by the bio-power and small hydro $[15,16]$. The Figure 9 shows and Table.1 give the completedetails of the various years with their increase in Generation units in both the generation capacity in billion units and percentage increment. In the above analysis the major generation from conventional sources was beetween 2014-2015 with 8.43\% growth [17-19].
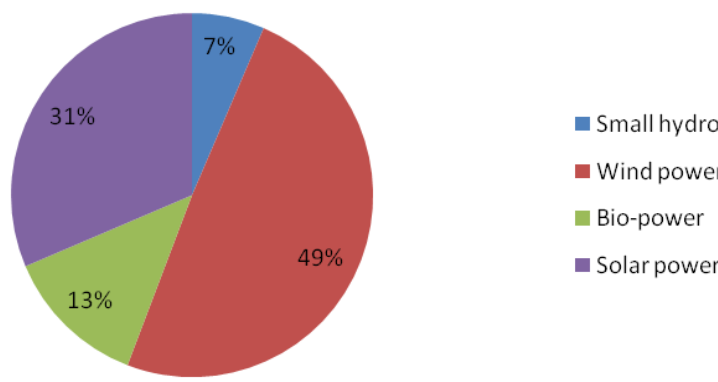

Figure 8. Renewable power installed capacity (MW)

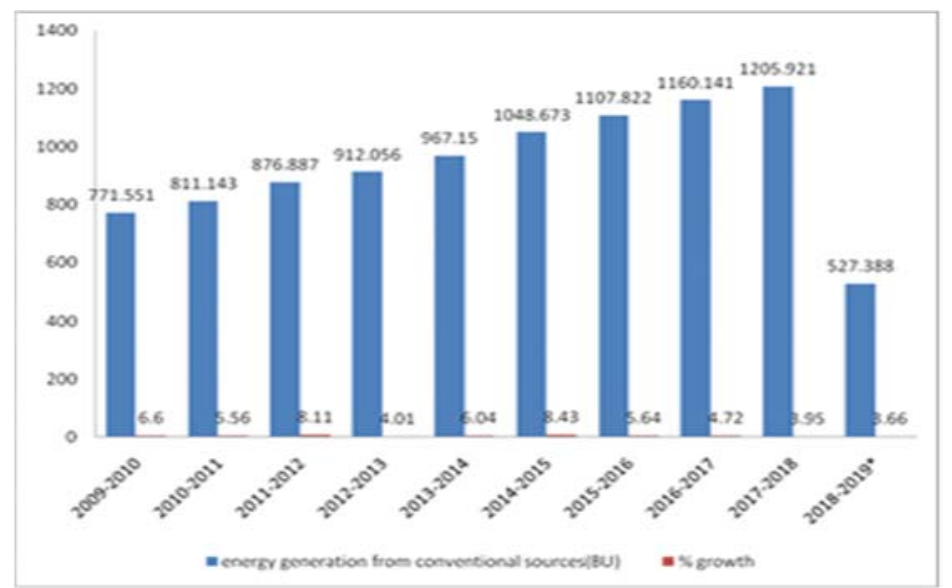

Figure 9. Yearwise growth in India

Table 1 Yearwise energy generation

\begin{tabular}{ccc}
\hline Various Years & $\begin{array}{c}\text { Energy generation from conventional } \\
\text { sources (BU) }\end{array}$ & \% Growth \\
\hline $2009-2010$ & 77.551 & 6.6 \\
$2010-2011$ & 811.143 & 5.56 \\
$2011-2012$ & 876.887 & 8.11 \\
$2012-2013$ & 912.056 & 4.01 \\
$2013-2014$ & 967.15 & 6.04 \\
$2014-2015$ & 1048.673 & 8.43 \\
$2015-2016$ & 1107.822 & 5.64 \\
$2016-2017$ & 1160.141 & 4.72 \\
$2017-2018$ & 1205.921 & 3.95 \\
$2018-2019$ & 527.388 & 3.66 \\
\hline
\end{tabular}

Figure 10 bar graph shows that how the PV installed capacity is increasing in the recent years of 2010-2018 [20, 21]. Where it is contributing a good proportion for overall generation. Since past few years, renewable energy has emerged as a significant player in the grid connected power generation capacity. By 
this government agenda is supported by the sustainable growth and it will be emerging as an integral part solution to meet the nation's consumer needs, which would be essential player for the access of energy. From past five years there is a visible impact in the Indian scenario for the renewable energy. Due to this there is a tremendous change in the policy framework with the accelerated and ambitious plans to increase the solar energy contributions.

With availability of technologies and capacity, there is a perception that renewable energy will play a significant role. The National Solar Mission symbolizes both enlarging the scope and encapsulates the vision and ambition for the future. The last five years of activities under the mission is the transformational change in this.

In last two years the government of India has taken several initiatives like the introduction of the concept of solar park, organizing a global investor's meet - RE-Invest 2015, launching program of a massive grid-connected rooftop solar, increment of CESS in clean environment of eight-fold from Rs.50 per ton to Rs.400 per ton, a scheme of installing 100000 solar pumps and program to train nearly 50000 people for installations of solar under the Surya Mitra scheme, no inter-state transmission charges and losses to be levied for solar and wind power, $100 \%$ procurement of power from waste to energy plants and renewable generations obligations on new thermal and lignite plants etc. The other major initiatives may be launching of improved cook-stoves; initiation research and development activities in solar PV and thermal; bio-fuels of the second generation; hydrogen energy and fuel cells etc [22-24].

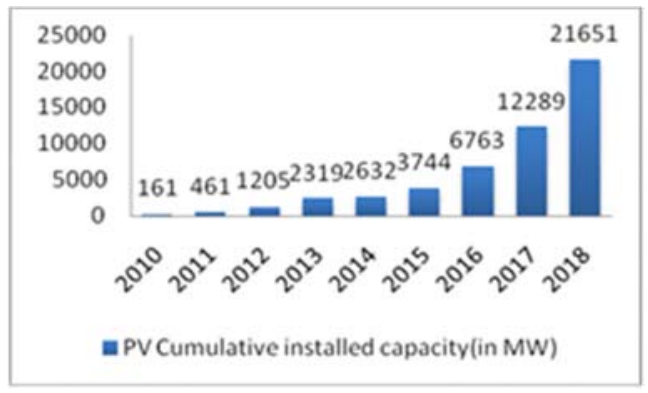

Figure 10. PV installed capacity (in MW)

The database of the renewable energy is regularly updated by the countries, it shown in Table 2 . The wind atlas of India was developed by the National Institute of Wind Energy (NIWE) formerly known as Centre for Wind Energy Technology. To develop the solar atlas of the country NIWE collects data from solar radiation resource assessment stations to assess and solar radiation availability is quantified. By taking $3 \%$ of the waste land and covered it by the PV modules by which National Institute of Solar Energy has assessed the State wise solar potential. The Indian Institute of Science, Bangalore has developed Biomass Atlas of India, and the Alternate Hydro Energy Centre, Indian Institute of Technology, Roorkee has assessed small hydro potential in the country.

Table 2. Electricity generations from renewable source

\begin{tabular}{crrrr}
\hline $\begin{array}{c}\text { Source wise all india } \\
\text { generation from the } \\
\text { renewable }\end{array}$ & \multicolumn{2}{c}{ For The month of } & \multicolumn{2}{c}{ Cumulative value for the period } \\
Nov 2017 & Nov 2016 & Nov 2016 \\
\hline Wind & 2435.88 & 1863.86 & 42375.01 & 37074.07 \\
Solar & 2112.58 & 1197.81 & 15086.13 & 8123.7 \\
Biomass & 268.76 & 335.15 & 2278.77 & 2742.56 \\
Biogass & 1455.13 & 1177.57 & 3868.08 & 4384.67 \\
Small hydro & 540.49 & 439.41 & 5949.32 & 6123.78 \\
Others & 81.22 & 16.07 & 582.07 & 121.59 \\
Total & 6894.06 & 5029.87 & 70134.38 & 58579.37 \\
\hline
\end{tabular}

Previous year china installed nearly $31 \mathrm{GW}$ of PV in which the $35 \%$ was lodged in the second quarter prior to the FiT reduction in mid-2016. For the year 2017 China's FiT scheme allows a grace period until 30 June 2017 for the permitted projects to get the 2016 tariff, which sets the stage for another strong

Int J Pow Elec \& Dri Syst Vol. 10, No. 4, Dec 2019 : 1995 - 2004 
second quarter, although which is smaller than the previous year. The IHS Markit projects China is to contract by $16 \%$ and in $201726 \mathrm{GW}$ installation, until the announcement of policies later this year that set off to a new wave installation.

As projects were required to be completed by the end of this year the United States installed 15GW. [25-27], In 2017 there was a uncertainty in demand as IHS Markit anticipates a 3GW decline, which was mainly in the utility-scale segment. Year-over-year in 2016, there was a shrunk in the Japan's PV demand by $23 \%$ and there was limited access to grid projects. Japan is expecting to decline by another $10 \%$ in 2017 by which it would become world's fourth-largest market. At projected installation of $10 \mathrm{GW}$, India is setting to take position as the third-largest PV market in 2017. However, there are remaining significant challenges which include access to land and financing. Through the goods and service tax there could be increase in prices by third quarter of 2017. In 2017, the 4 largest PV markets will represent only the three quarters of PV demand in global. Back of the declining module prices, the smaller markets are growing, this growth will not be enough to counterweigh impact of demand fluctuations in the largest market. By 2021, a total of 450GW globally there will be new PV installations. This Figure 11 shows that $141 \%$ growth in cumulative installed PV generation capacity [28-31]. Here are the top 10 producers of PV for 2018 according to a report from energy trend in PV magazine, Figure 12.

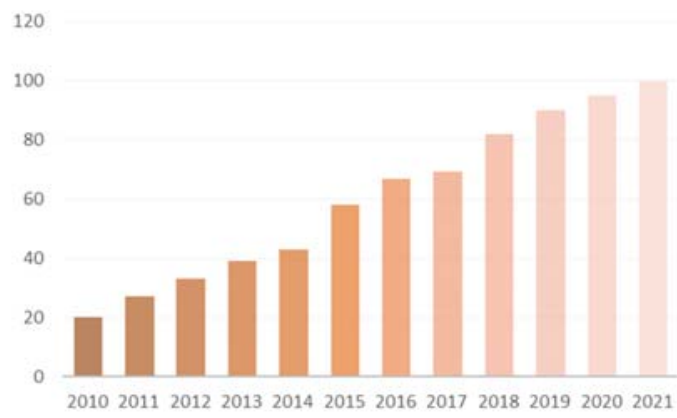

Figure 11 Annual PV installation in India.

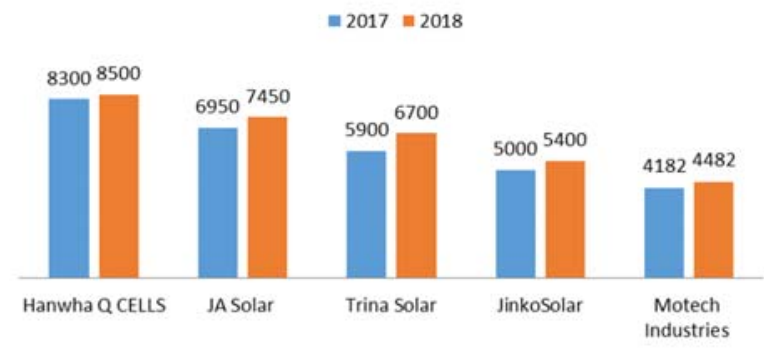

Figure 12 Top ten solar power suppliers in world

\section{CONCLUSION}

Due to drastic increase in consumption of the consumption fuels through generation of power, commercial, domestic purposes etc. by which the world is affected and causing global warming effect which is very hazardous to not only human life but also to the nature and globe. So, we have to identify the countries which are severe regarding the global warming and have to work on the issue. By this countries should start leaving the generation through the fossil fuels and replace them by the renewable resources and with the improvement in the technologies. Up to know the most renewable energy is produced through the solar and it's the dominant among all. Electricity production through the solar energy resources decreases the carbon dioxide emissions as its technology is environmentally friendly.

To reach the consumers and have a good impact on the growth there should be a flexible financial retail. Either the investors or the consumers should be given subsidiaries so that the establishment of solar plant and buying of the solar panels is easier. 


\section{REFERENCES}

[1] Bob Dudely,et,al. BP Statistical Review of World Energy. Edition: 66,June-2017.United Kingdom

[2] Chrisstine Lins, REN-21, et, all Renewables 2017, "Global Status Report.” PARIS

[3] Chrisstine Lins, REN-21, et, all Renewables 2018, "Global Status Report." PARIS

[4] Ehsanul Kabir and Pawan Kumar, "Solar energy: Potential and future prospects", Renewable and Sustainable Energy Reviews, vol. 82, pp. 894-900, 2018.

[5] Wang F, Yin H, Li S. China's renewable energy policy: commitments and challenges. Energy Policy 2010; Renewable and Sustainable Energy Reviews,” vol. 38, no. 4, pp. 1872-8, April 2017.

[6] Yang H, Wang H, Yu H, Xi J, Cui R, Chen G. "Status of photovoltaic industry in China", Energy Policy, vol. 31, no. 8, pp. 703-7, 2003;

[7] Liu LQ, Wang ZX, Zhang HQ, Xue YC. "Solar Energy development in China-A review", Renewable and sustainable Energy Reviews, Vol. 14, No. 1, pp. 301-11, January 2010.

[8] Matthew Wittenstein, et. all, "International Energy Agency (IEA)/Nuclear Energy Agency (NEA)", Projected Cost of Generating Electricity; IEA/NEA: Paris, France, 2015.

[9] Matthew Wittenstein, et,all. "U.S. Energy Information Administration (EIA)", Country Analysis Brief: South Korea.United States.

[10] Adrian Whiteman, Tobias Rinke, Javier Esparrago, "International Renewable Energy Agency (IRENA)", Renewable Energy Capacity, Abu Dhabi, 2017.

[11] Ministry of Trade, Industry and Energy. The Second Korea Energy Master Plan. Outlook \& Policies to 2035; Rep. of Korea; Ministry of Trade, Industry and Energy: Sejong City, Korea, 2014.

[12] Chamola, V.; Sikdar, B. "Solar powered cellular base stations: Current scenario, issues and proposed solutions", IEEE Commun. Mag. Vol. 54, pp. 108-114, 2016.

[13] Urja Akshay, et.all. "Renewable Energy in India current status and future potential", MOP, October, 2008.

[14] Press Information Bureau, Year End Review, Government of India, Ministry of New and Renewable Energy, 27 December 2017.

[15] L.P, Bloomberg, Henry Albert, et.all. "The Bloomberg New Energy Finance Report (BNEF)” July, 2018, United States.

[16] Planning Commission, Government of India-September 1995 and September 1996 Projections to 2020-2021.

[17] Sharma, A., "A comprehensive study of solar power in India and World." Renewable and Sustainable Energy Reviews, Vol. 15, No. 4, pp. 1767-1776, 2011.

[18] Furkan Dinc,er, "The analysis on photovoltaic Electricity generation status, potential and policies of the leading countries in solar energy," Renewable and Sustainable Energy Reviews, Vol. 15, pp. 713-720, 2011.

[19] Hrayshat ES. "Analysis of renewable energy situation in Jordan", Renewable and Sustainable Energy Reviews, vol 11, no. 8, pp. 1873-87; 2007.

[20] Speed PA. "China's ongoing energy efficiency drive: origins, progress and prospects", Energy Policy, Vol. 37, No. 4: pp. 1331-44, 2009.

[21] Huang YH, Wu JH. "Technological system and renewable energy policy: a casestudy of solar photovoltaic in Taiwan", Renewable and Sustainable Energy Reviews. Vol. 11, No. 2, pp. 345-56, 2007.

[22] Chen F, Duic N, Alves LM, Carvalho MG. "Renewislands-Renewable energy solutions for islands", Renewable and Sustainable Energy Reviews, vol. 11, no. 8, pp. 1888-902, 2007.

[23] Kalogirou S. "Solar energy engineering: processes and systems", Academic Press; 2009. p. 469-517 [chapter 9].

[24] Bahaj AS. "Means of enhancing and promoting the use of solar energy", Renewable Energy, vol. 27, no. 1, pp. 97-105, 2002.

[25] Nowak S, Aulich H, Bal JL, Dimmler B, Garnier A, Jongerden G, et al. "The European photovoltaic technology platform”, IEEE Photovoltaic Energy Conversion Conferences 2006, pp. 2485-9, 2006.

[26] Commission of the European Communities, Com (2008) 0019. Proposal for a Directive of the European Parliament and of the Council on the promotion of the use of energy from renewable sources, Brussels; 2008.

[27] Di'ez-Mediavilla M, Alonso-Trista'n C, Rodr1'guez-Amigo MC, Garc1'a-Caldero'nT. "Implementation of PV plants in Spain: a case study", Renewable and Sustainable Energy Reviews, vol. 14, no. 4, pp. 1342-6, 2010.

[28] K.Kannan, Sutha Padmanabhan.] "Closed loop control of excitation parameters for High speed switched reluctance generator using MATLAB/SIMULINK", International Journal on Electrical Engineering and Informatics, Vol. 2, no. 3, pp. 232-243, 2010.

[29] K.Kannan,Sutha Padmanabhan "PI-CCC Based Switched Reluctance Generator Applications for Wind Power Generation Using MATLAB/SIMULINK", Journal of Electrical and Engineering Technology, : Issn:19750102,vol.8[2],pages[230-237],2013.

[30] K.Kannan, Sutha Padmanabhan, "GRID Based Switched Reluctance Generator Applications for wind power generation on MPPT algorithm using MATLAB/SIMULINK”, European Journal of Scientific Research, vol. 100, no. 4, pp. 579-591, 2013.

[31] K.Kannan,Sutha Padmanabhan "High Performance MPPT Based on variable speed Generator driven by Wind Power Generation in Battery Applications", Journal of Electrical and Engineering Technology, vol .9, no.1, pp. 205-213, 2014.

Int J Pow Elec \& Dri Syst Vol. 10, No. 4, Dec 2019 : 1995 - 2004 